\title{
Pengaruh Budaya Sekolah Terhadap Karakter Religius Siswa di SD IT Noor Hidayah
}

\author{
Intan Nuraeni, Erna Labudasari \\ Universitas Muhammadiyah Cirebon \\ ernalabuda22@gmail.com
}

\section{Article History}

received 30/5/2021

\begin{abstract}
This research is motivated by the scarcity of religious school culture in several schools which serves to prevent moral degradation. However, SD IT Noor Hidayah is one of the schools that has a special program of Islamic education and school culture in the religious field which aims to improve the religious character of students. This study aims to determine the school culture in SD IT Noor Hidayah; Knowing the religious character of SD IT Noor Hidayah students, and Knowing the influence of school culture on the religious character of students at SD IT Noor Hidayah. This study uses a quantitative survey research method. Data were collected through observation, interviews, questionnaires, and documentation techniques. The subjects in this study were all 124 students of SD IT Noor Hidayah, and the samples in this study were 31 students in grades 1-4. The results show that the culture of religious schools in SD IT Noor Hidayah includes reading prayers together in class; reading short letters of the Qur'an, and praying dhuha and dzuhur prayers in congregation. School culture has an effect of $29.2 \%$ on the character of students. This school culture has a significant effect on the religious character of SD IT Noor Hidayah students. The positive relationship between the two variables implies that the better the school culture is designed, the better the character of the school community, especially the character of the students.
\end{abstract}

Keywords: Moral Degradation, School Culture, Religious Character

\begin{abstract}
Abstrak
Penelitian ini dilatarbelakangi oleh kelangkaannya budaya sekolah keagaamaan di beberapa sekolah yang berfungsi untuk mencegah degradasi moral. Namun, SD IT Noor Hidayah merupakan salah satu sekolah yang memiliki program khusus pendidikan Islam dan budaya sekolah pada bidang keagamaan yang bertujuan untuk meningkatkan karakter religius siswa. Penelitian ini bertujuan untuk mengetahui budaya sekolah yang ada di SD IT Noor Hidayah; Mengetahui karakter religius siswa SD IT Noor Hidayah; dan Mengetahui pengaruh antara budaya sekolah terhadap karakter religius siswa di SD IT Noor Hidayah. Penelitian ini menggunakan metode penelitian kuantitatif survey. Data yang dikumpulkan melalui teknik observasi, wawancara, kuesioner dan dokumentasi. Subjek dalam penelitian ini adalah seluruh siswa SD IT Noor Hidayah yang berjumlah 124 siswa, dan yang menjadi sampel pada penelitian ini adalah 31 siswa kelas 1-4. Hasil penelitian menunjukkan bahwa budaya sekolah keagamaan yang terdapat di SD IT Noor Hidayah yaitu meliputi pembacaan do'a bersama di kelas; pembacaan surat-surat pendek Al-Qur'an, dan sholat dhuha dan sholat dzuhur berjamaah. Budaya sekolah berpengaruh sebesar 29,2\% terhadap karakter siswa. Budaya sekolah ini berpengaruh cukup signifikan terhadap karakter religius siswa SD IT Noor Hidayah. Hubungan positif antara kedua variabel tersebut yang mengandung makna semakin baik budaya sekolah yang dirancang, maka semakin baik pula karakter warga sekolah terutama karakter siswanya.
\end{abstract}

Kata kunci: Degradasi Moral, Budaya sekolah, Karakter Religius 


\section{PENDAHULUAN}

Pembentukan karakter peserta didik menjadi salah satu tujuan pendidikan yang diserukan pemerintah. Dalam pembentukan karakter yang baik diperlukan suatu pendidikan karakter. Menurut Ki Hajar Dewantara dalam kongres Taman Siswa pada tahun 1930 pendidikan karakter merupakan gabungan dari dua kata, yaitu pendidikan dan karakter yang umumnya berarti daya upaya untuk memajukan bertumbuhnya budi pekerti (kekuatan batin, karakter), pikiran (intelek), dan tubuh anak. Sedangkan, menurut Sternberg dalam (Darmini, 2015) mengemukakan pengertian pendidikan karakter adalah upaya yang dilakukan dengan sengaja untuk mengembangkan karakter yang baik (good character) berlandaskan kebijakan-kebijakan inti (cover virtuse) yang secara objektif baik bagi individu maupun masyarakat. Maka dapat disimpulkan pendidikan karakter merupakan sebuah upaya untuk menumbuhkan dan mengembangkan karakter baik.

Terdapat beberapa macam karakter yang perlu dikembangkan Berdasarkan Kementerian Pendidikan Nasional Badan Penelitian Dan Pengembangan Pusat Kurikulum. Ada 18 nilai pendidikan budaya dan karakter bangsa, yaitu: (a) Religius; (b) Jujur; (c) Toleransi; (d) Disiplin; (e) Kerja Keras; (f) Kreatif; (g) Mandiri; (h) Demokratis; (i) Rasa Ingin Tahu; (j) Semangat Kebangsaan; (k) Cinta Tanah Air; (I) Menghargai Prestasi; (m) Bersahabat/Komunikatif; (n)Cinta Damai; (o) Gemar membaca; (p) Peduli Lingkungan; (q) Peduli Sosial dan (r) Tanggung Jawab (Suyadi, 2018). Berdasarkan karakter tersebut, karakter religius merupakan salah satu karakter pertama dan utama yang harus ditanamkan kepada anak sedini mungkin yang menjadi dasar ajaran agama dalam kehidupan individu, masyarakat dan bangsa indonesia (Nurbaiti et al., 2020). Pembentukan karakter religius ini tentu dapat dilakukan jika seluruh komponen stakeholders dapat berpartisipasi dan berperan serta (Shoumi, 2017). Berdasarkan hal tersebut, maka penting bagi sekolah untuk mencari strategi yang dapat berpengaruh secara signifikan terhadap karakter religius siswa.

Sekolah memiliki peran yang besar dalam pembentukan karakter siswa, khususnya karakter religius yang menjadi landasan utama dalam pendidikan karakter. Setiap lembaga sekolah tentu memiliki strategi yang berbeda-beda terkait bagaimana sekolah menanamkan karakter religius kepada siswa (Kurniawan, 2019). Pembentukan karakter di sekolah dapat dilakukan melalui budaya sekolah. Kultur sekolah atau budaya sekolah terbentuk dari berbagai macam norma, pola perilaku, sikap, dan keyakinan-keyakinan yang dimiliki oleh para anggota komunitas sebuah lembaga pendidikan (Supraptiningrum \& Agustini, 2015). Tujuan dari budaya sekolah adalah untuk membangun suasana sekolah yang kondusif melalui pengembangan komunikasi dan interaksi yang sehat antara kepala sekolah dengan peserta didik, pendidik, tenaga kependidikan, orang tua peserta didik, masyarakat dan pemerintah. Budaya sekolah memegang peranan penting dalam penanaman nilai pendidikan karakter di sekolah. Proses implementasi pendidikan karakter dalam budaya sekolah menjadi sangat penting dalam membentuk karakter siswa yang lebih kuat (Anggraini \& Zulfiati, 2017).

Pendidikan karakter berbasis nilai religius juga dapat diistilahkan dengan pendidikan karakter berbasis agama. Pendidikan karakter berbasis agama merupakan pendidikan yang menegembangkan nilai-nilai yang berdasarkan agama yang membentuk kepribadian, sikap, dan tingkah laku yang utama atau luhur dalam kehidupan. Nilai religius tersebut dapat dibentuk melalui budaya sekolah sehingga budaya sekolah yang diterapkan dalam pembentukan karakter merupakan budaya sekolah yang religius (Silkyanti, 2019). Untuk membentuk karakter religius siswa dapat dilakukan dengan cara menerapkan budaya sekolah yang berkaitan dengan nilai-nilai keagamaan. Menurut Deal dan Peterson, budaya sekolah sebagai sekumpulan nilai yang melandasi perilaku, tradisi, kebiasaan, keseharian, dan symbol-simbol yang dipraktikkan oleh kepala sekolah, guru, petugas administrasi, siswa, masyarakat 
sekitar sekolah (Muhaimin, 2006). Budaya sekolah memiliki peran sangat penting, karena apabila budaya sekolah sudah terlaksana, siapapun yang masuk dan bergabung ke sekolah itu hampir secara otomatis akan mengikuti tradisi yang telah ada. Budaya sekolah menurut penelitian (Labudasari \& Rochmah, 2018) dibagi menjadi tiga macam, diantaranya budaya keagamaan, budaya kesehatan, dan budaya kesenian. Dan dalam penelitian ini, budaya sekolah yang ingin diteliti yaitu budaya keagamaan yang memiliki peran dalam pembentukan karakter religius. Alasannya adalah sejalan dengan Peraturan Presiden No. 87 Tahun 2017 tentang Program Penguatan Pendidikan Karakter, yang ditindaklanjuti dengan Keputusan Menteri Pendidikan dan Kebudayaan RI Republik Indonesia Nomor 20 Tahun 2018 tentang Penguatan Karakter Pendidikan di satuan pendidikan formal untuk memperkuat lima inti karakter bangsa dan salah satunya adalah nilai agama (Muhtar et al., 2019). Berdasarkan hal tersebut, maka dapat disimpulkan bahwa karakter religius sangat dibutuhkan oleh siswa dalam menghadapi perubahan zaman dan degradasi moral, dalam hal ini siswa diharapkan mampu memiliki dan berperilaku dengan ukuran baik dan buruk yang didasarkan pada ketentuan dan ketetapan agama.

Budaya keagamaan atau budaya religius merupakan upaya pengembangan pendidikan untuk mewujudkan tujuan pendidikan Nasional. Karena dalam UndangUndang Sistem Pendidikan Nasional (UUSPN) No. 20 tahun 2003 pasal 1 dijelaskan bahwa Pendidikan adalah usaha sadar dan terncana untuk mewujudkan suasana belajar dan proses pembelajaran agar peserta didik secara aktif mengembangkan potensi dirinya untuk memiliki kekuatan spiritual keagamaan, pengendalian diri, kepribadian, kecerdsasan, akhlak mulia, serta ketrampilan yang diperlukan dirinya, masyarakat dan Negara (Fathurrohman, 2015). Budaya religius sekolah merupakan cara berpikir dan cara bertindak warga sekolah yang didasarkan atas nilai-nilai religius (keagamaan). Anak-anak akan tumbuh menjadi pribadi yang berkarakter jika ia tumbuh pada lingkungan yang berkarakter pula. Oleh karena itu, penanaman atau pendidikan karakter bagi anak menjadi penting. Pembentukan watak ini dapat dikatakan sebagai upaya membentuk karakter. Pembentukan karakter dipengaruhi oleh faktor genetik dan lingkungan. Lingkungan memiliki pengaruh yang signifikan pada kepribadian manusia. Seorang anak memiliki waktu yang cukup banyak untuk berada dilingkungan sekolah, apalagi jika sekolahnya berbasis full day school.

Berdasarkan observasi awal yang dilakukan di Sekolah Dasar Islam Terpadu Noor Hidayah, sekolah ini berbasis full day school. Kegiatan pembelajaran dimulai sejak pukul 07.00 dan berakhir pukul 16.00. Oleh karenanya siswa yang bersekolah disini, akan berinteraksi lebih lama di lingkungan sekolah dibandingkan dengan lingkungan lainnya. Melalui pembiasaan di lingkungan sekolah, diharapkan siswa dapat mengembangkan potensinya dan dapat mengalami perubahan perilakunya menjadi lebih baik. Dengan demikian, watak atau karakter dapat dibentuk melalui pendidikan yang didapatkan manusia dari lingkungan belajarnya seperti sekolah.

SD IT Noor Hidayah memiliki visi Terwujudnya Generasi CIReBON (Cerdas, Inovatif, Religius, Berakhlak mulia, Obyektif, Normatif). SD IT Noor Hidayah baru berdiri empat tahun, akan tetapi sudah memiliki akreditasi $A$ dan banyak orang tua yang berminat untuk menyekolahkan anaknya ke sekolah yang berbasis full day school itu,dikarenakan SD IT Noor Hidayah termasuk lembaga yang berbeda dengan sekolah lain karena memadukan materi pelajaran umum dengan materi agama secara seimbang, dengan harapan mampu membentuk sumber daya manusia yang aktif, kreatif, dan berprestasi sesuai dengan perkembangan zaman dan melahirkan bibit-bibit yang unggul dibidang IMTAK dan IPTEK serta mengkondisikan siswa pada lingkungan kehidupan generasi Robbani.

SD IT Noor Hidayah berupaya menumbuhkan kegemaran membaca, memahami, dan menghafal Al-Qur'an serta menggali berbagai potensi kecerdasan dan ketrampilan yang ada pada anak sehingga mampu bereksplorasi demi mewujudkan anak didik 
yang berprestasi. Adapun program pendidikan Islam menjadi program khusus di SD IT Noor Hidayah. Selain itu budaya yang diterapkan juga beda dengan sekolah lain, budaya yang diterapkan di SD IT Noor Hidayah yaitu 3S (senyum, sapa, salam); berdo'a dan membaca asmaul husna sebelum kegiatan belajar dimulai; sholat dhuha berjamaah; sholat dzuhur berjamaah; sholat ashar berjamaah; makan siang bersama; shodaqoh; menaruh sandal dan sepatu pada tempatnya; berwudhu sebelum sholat; sholat jum'at berjamaah di masjid untuk guru laki-laki dan siswa laki-laki; tahfidzul qur'an; hafalan hadits dan do'a sehari-hari. Selain budaya sekolah yang religius siswa juga mendapatkan mata pelajaran yang ada di madrasah seperti fikih, aqidah akhlak, sejarah kebudayaan islam, qur'an hadits, dan bahasa arab. Kegiatan-kegiatan yang telah disebutkan merupakan budaya sekolah dan diharapkan dapat berpengaruh terhadap perkembangan karakter religius siswa.

Penelitian ini dilakukan di SD IT Noor Hidayah, dikarenakan sekolah tersebut memiliki budaya sekolah yang menanamkan siswanya nilai-nilai agama sehingga dapat membentuk karakter religius siswa. Akan tetapi, tidak semua siswa menerapkan budaya sekolah yang memiliki pengaruh dalam pembentukan karakter religius siswa. Hal ini dapat dilihat ketika sholat dzuhur berjamaah, tidak semua siswa laki-laki ada dimasjid sekolah melainkan ada yang dikantin sekolah dan ada yang asyik bermain.

Berdasarkan hasil penelitian yang telah dilakukan oleh (Andari, 2013) menunjukkan bahwa terdapat pengaruh yang positif antara budaya sekolah dengan karakter siswa. Dimana apabila budaya sekolah meningkat 1\% maka akan diikuti pula peningkatan karakter siswa sebesar $0,384 \%$, dimana semakin baik budaya sekolah semakin baik pula karakter siswa. Karakter siswa dipengaruhi oleh budaya sekolah sebesar $17,4 \%$, sedangkan $82,6 \%$ dipengaruhi oleh faktor lain di luar dari variabel dalam penelitian yang digunakan.

Berdasarkan penjelasan diatas, penulis tertarik untuk mengambil penelitian mengenai "Pengaruh Budaya Sekolah Terhadap Karakter Siswa Di SD IT Noor Hidayah". Adapun tujuan dari penelitian ini adalah untuk mengetahui budaya sekolah dalam bidang keagamaan di SD IT Noor Hidayah; mengetahui karakter religius siswa; Mengetahui pengaruh budaya sekolah dalam bidang kegamaan terhadap karakter religuus siswa di SD IT Noor Hidayah.

\section{METODE}

Penelitian ini merupakan penelitian kuantitatif survey dengan analisis deskriptif dengan pendekatan kuantitatif. Metode survey menurut (Wahidin, K., 2010) adalah metode yang digunakan untuk melakukan perbandingan atau analisis hubungan antar variabel. Penelitian ini dilakukan untuk meneliti Pengaruh Budaya Sekolah Terhadap Karakter Religius Siswa di SD IT Noor Hidayah. Populasi pada penelitian adalah 124 siswa dari kelas 1-4. Berdasarkan teknik pengambilan sample yaitu purposive sampling, peneliti mengambil sample dengan pertimbangan melihat nilai mata pelajaran agama. Menurut (Arikunto, 2013) apabila jumlah responden kurang dari 100, maka sampel diambil semua. Jika jumlah responden lebih dari 100, maka sampel diambil semua dengan 10\% - 15\% atau 20\% - 25\% atau lebih. Maka, sampel yang digunakan sebanyak 31 siswa terdiri dari kelas 1 berjumlah 7 siswa, kelas 2 berjumlah 8 siswa, kelas 3 berjumlah 8 siswa, dan kelas 4 berjumlah 8 siswa.

Instrumen penelitian yang digunakan berupa observasi, angket, wawancara dan studi dokumenter. Adapun indikator dari budaya sekolah yang digunakan adalah meliputi pembacaan do'a bersama di kelas; Pembacaan surat-surat pendek Al-Qur'an; dan Sholat dhuha dan Sholat dzuhur berjamaah (Labudasari \& Rochmah, 2018). Indikator karakter religius meliputi Mengucapkan salam; Berdo'a sebelum dan sesudah belajar; Melaksanakan ibadah keagamaan; dan Merayakan hari besar keagamaan 
(Asmani, 2013). Adapun analisis data yang dilakukan melalui uji prasarat yang terdiri dari uji normalitas dan linieritas, kemudian dilanjutkan dengan uji hipotesis.

\section{HASIL DAN PEMBAHASAN}

Pada penelitian ini rumusan masalahnya adalah: 1) bagaimana budaya sekolah dalam bidang keagamaan di SD IT Noor Hidayah, 2) bagaimana karakter religius siswa di SD IT Noor Hidayah, 3) adakah pengaruh budaya sekolah dalam bidang keagamaan terhadap karakter religius siswa di SD IT Noor Hidayah. selanjutnya, untuk menjawab rumusan masalah tersebut disajikan pada pembahasan berikut:

\section{Budaya Sekolah}

Pengembangan karakter religius di sekolah adalah sesuatu yang sangat urgen untuk dilakukan. Urgensi pengembangan budaya agama di sekolah adalah agar seluruh warga sekolah memperoleh kesempatan untuk dapat memiliki bahkan mewujudkan seluruh aspek keberagamaannya baik pasa aspek keyakinan (keimanan), praktik agama, pengalaman, pengetahuan agama, dan dimensi pengamalan keagamaan. Semua itu dapat diwujudkan melalui berbagai kegiatan keagamaan sebagai wahana dalam upaya menciptakan dan mengembangkan budaya religius di sekolah (Suryana, 2013). Pelaksanaan nilai religius dalam pendidikan karakter yang di lakukan di sekolah yaitu dengan melakukan kegiatan-kegiatan keagamaan yang dilakukan secara rutin yang dijadikan budaya sekolah sehingga siswa akan terbiasa melakukan dan menerapkannya tidak hanya dalam lingkungan sekolah tetapi juga ketika mereka di rumah (Arifa, 2017). Berdasarkan hal tersebut, Budaya sekolah yang ada di sekolah tentunya akan membantu siswa untuk mengembangkan karakternya.

Budaya sekolah adalah sekumpulan nilai yang melandasi perilaku, tradisi, kebiasaan sehari-hari, dan simbol-simbol yang dipraktekkan oleh kepala sekolah, pendidik/guru, petugas tenaga kependidikan/administrasi, peserta didik, masyarakat sekitar sekolah. Budaya sekolah mempunyai ciri khas, karakter atau watak dan citra sekolah tersebut di masyarakat luas. Budaya sekolah harus memiliki misi yang jelas dalam menciptakan budaya sekolah yang menantang dan menyenanggkan, adil, kreatif, inovatif, terintegratif, serta dedikatif terhadap pencapaian visi, menghasilkan lulusan yang berkualitas tinggi dalam perkembangan intelektualnya. Selain itu, mempunyai karakter takwa, jujur, kreatif, mampu menjadi teladan, bekerja keras, toleran dan cakap dalam memimpin, serta menjawab tantangan akan kebutuhan pengembangan sumber daya manusia yang berperan dalam perkembangan IPTEK dan berlandasan IMTAK (Munzier dalam (Suwandayani \& Isbadrianingtyas, 2017)).

Budaya sekolah merupakan kebiasaan warga sekolah yang sudah terbentuk sejak lama. Menurut (Nur, 2017) bentuk budaya agama (religius) yang dikembangkan ada 3 (tiga) katagori, yaitu; a) bentuk budaya ibadah ilahiah; b) bentuk budaya ibadah sosial; c) bentuk budaya ibadah lingkungan hidup. Berdasarkan penelitian yang telah dilakukan oleh (Labudasari \& Rochmah, 2018) budaya sekolah terbagi menjadi tiga macam yaitu budaya keagamaan, kesehatan, dan kesenian. Budaya keagamaan meliputi kegiatan pembacaan doa bersama di kelas; pembacaan surat-surat pendek Al-Quran; Sholat dhuha dan sholat dzuhur berjamaah. Berdasarkan hal tersebut, dalam penelitian ini budaya sekolah yang ada di SD IT Noor Hidayah yaitu budaya keagamaan, dimana budaya keagamaan memiliki tiga indikator yang telah ditentukan, indikator yang pertama yaitu pembacaan do'a bersama di kelas, indikator yang kedua pembacaan surat-surat pendek Al-Qur'an, dan indikator yang ketiga sholat dhuha dan sholat dzuhur berjamaah. Berdasarkan hasil wawancara dengan kepala sekolah, indikator yang telah disebutkan tadi sudah diterapkan dan sudah menjadi pembiasaan bagi warga sekolah khususnya siswa di SD IT Noor Hidayah. 
Adapun cara yang dapat dilakukan dalam mengembangkan budaya sekolah menurut (Daryanto \& Darmiatun, 2013) yaitu dengan melakukan kegiatan rutin misalnya konsisten dalam pelaksanaan sholat dhuha berjamaah, pemberian contoh tindakan yang baik atau keteladanan, dan kegiatan spontan misalnya mengambil menolong teman yang jatuh. Berdasarkan hal tersebut, peneliti melakukan observasi dan menyebarkan angket yang berisikan seputar kegiatan keagamaan yang rutin dilakukan dalam rangka untuk mengetahui budaya sekolah yang ada d SD IT Noor Hidayah.

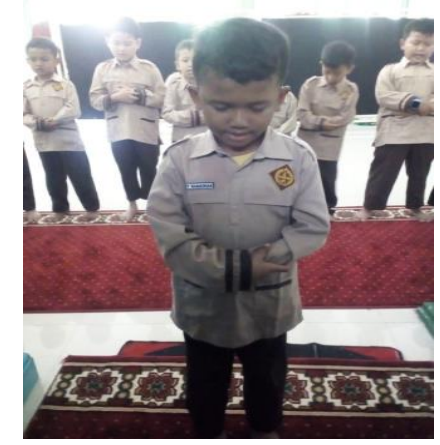

\section{Gambar 1. Pembiasaan Sholat Dhuha Berjamaah di Kelas 1}

Angket pada responden (siswa) yang berisi 12 butir pernyataan pada masingmasing variabel. Melalui angket, didapatkan hasil bahwa SD IT Noor Hidayah memiliki budaya sekolah yang religius dan sudah diterapkan oleh warga sekolah khususnya para siswa. Budaya religius yang ada di SD IT Noor Hidayah jika dilihat berdasarkan tabel distribusi frekuensi sangat tinggi yaitu 67.55\%. Adapun indikator budaya sekolah khususnya budaya keagamaan di SD IT Noor Hidayah sudah terlaksana dan sudah menjadi pembiasaan, seperti berdo'a sebelum dan sesudah belajar, sholat berjamaah, serta memperingati hari-hari besar Islam. Kegiatan-kegiatan tersebut tidak hanya dilakukan oleh siswa, melainkan dilakukan oleh semua warga sekolah seperti kepala sekolah, guru, dan juga staf TU.

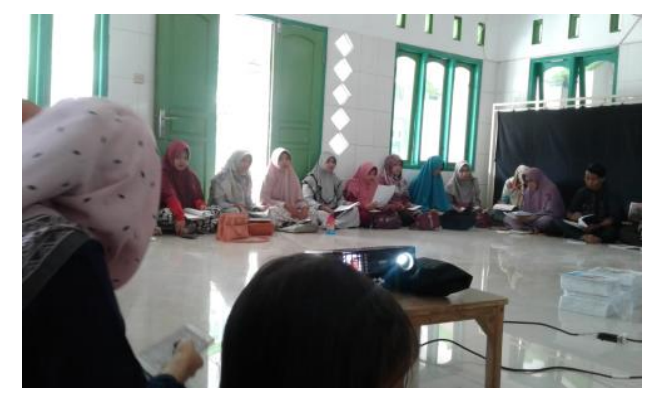

\section{Gambar 2. Kegiatan Pelatihan Mengaji untuk Guru}

Untuk mewujudkan suatu budaya sekolah yang religius dibutuhkannya dukungan dari semua pihak untuk bersama-sama memberikan komitmen dalam menanamkan nilai-nilai yang dapat diterapkan di lingkungan sekolah khususnya dalam bidang keagamaan. Menurut (Fathurrohman, 2015), faktor terwujudnya suatu budaya religius adalah adanya dukungan dari pimpinan, guru, dan masyarakat. Berdasarkan hasil penelitian yang telah dilakukan, peneliti melihat jika pimpinan lembaga atau yayasan sangatlah memberikan dukungan dalam penciptaan budaya sekolah yang religius, hal ini dibuktikan dengan adanya fasilitas berupa tempat beribadah (Musholah) yang dilengkapi dengan tempat wudhu, pengeras suara, perlengkapan ibadah seperti 
sajadah, mukenah, dan Al-Qur'an. Selain memberikan fasilitas untuk beribadah, pimpinan juga memberikan pelatihan mengaji setiap bulannya yang diikuti oleh semua guru yang ada.

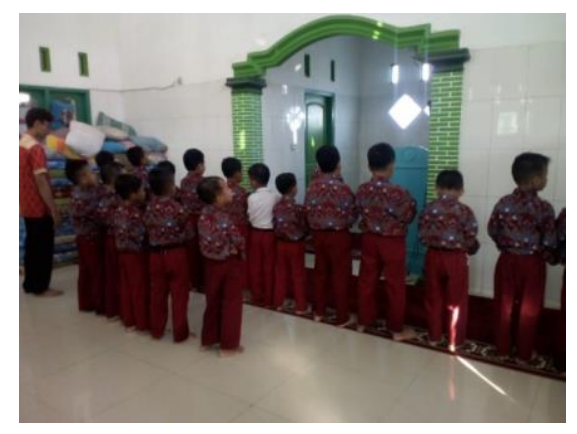

\section{Gambar 3. Kegiatan Sholat Dhuha didampingi oleh Guru}

Selain pimpinan lembaga, dukungan yang tidak kalah penting yaitu dukungan dari para guru. Guru sangat berperan dalam mengembangkan suatu budaya sekolah yang diinginkan. Melalui kegiatan pembiasaan setiap harinya guru-guru di SD IT Noor Hidayah selalu mendampingi, mengarahkan, dan menjadi teladan bagi siswanya. Biasanya, guru akan mendampingi siswanya ketika sholat berjamaah, mengarahkan siswanya untuk selalu berbuat kebaikan seperti mengingatkan kepada siswanya untuk sholat tepat waktu, berkata jujur, dan hidup rukun dengan sesama. Guru juga dapat dijadikan teladan bagi siswanya, misalnya pada saat siswanya ribut ketika sedang berada di dalam musholah atau sedang dalam proses belajar mengajar, guru tidak akan memarahi siswanya melainkan hanya menegur dan memberikan pemahaman atau nasehat pada siswa dengan lemah lembut dan penuh kesabaran. Selain itu, guru juga bertugas membuat jadwal pelaksanaan kegiatan keagaaman agar kegiatan dapat berjalan dengan lancar dan terorganisir dengan baik dan seluruh kelas di SD IT Noor Hidayah dapat melakukan kegiatan secara bergantian.

Selain dukungan dari pimpinan dan guru, dukungan dari luar atau masyarakat sangatlah dibutuhkan dalam mengembangkan budaya sekolah. Masyarakat sekitar sekolah sangat memberikan partisipasinya pada program-program yang telah dibuat oleh pihak sekolah. Biasanya masyarakat akan menghadiri acara-acara yang dibuat oleh sekolah seperti acara buka bersama yang diadakan setiap tahun sekali dan acara sholat tarawih berjamaah. Dengan mengikutsertakan masyarakat sekitar maka akan memudahkan pihak sekolah dalam mewujudkan tujuan sekolah dan mengembangkan budaya sekolah yang ada.

Sejalan dengan pendapat Deal \& Kennedy (Tarmidzi \& Sugiarti, 2019) yang menyebutkan bahwa kultur sekolah atau budaya sekolah menurut meliputi ketentuan dan norma yang disepakati dan menjadi pengikat kuat kebersamaan seluruh warga masyarakat (sekolah). Budaya sekolah yang diimplementasikan di SD IT Noor Hidayah, dapat mempererat hubungan khususnya antara guru dan siswa karena pelaksanaan budaya sekolah melibatkan seluruh masyarakat sekolah. Guru memberikan contoh dan teladan yang baik dalam kegiatan rutin keagamaan seperti melaksanakan sholat berjamaah di masjid sekolah. Kegiatan praktek ibadah bertujuan agar seorang guru mengetahui sejauh mana siswanya hafal bacaan-bacaan sholat dan tahu gerakan-gerakan sholat yang benar. Apabila ada kesalahan, maka disitulah tugas guru untuk memberitahu tata cara beribadah yang benar. (Tarmidzi \& Sugiarti, 2019) menyebutkan bahwa karakter dan pola pikir anak di sekolah dibentuk melalui kultur (budaya) serta kebiasaan dan pembiasaan positif di sekolah. Oleh sebab itu, Berdasarkan hasil penelitian, budaya sekolah di SD IT Noor Hidayah perlu dikembangkan lagi agar dapat mencapai tujuan yang lebih maksimal yaitu dalam 
rangka mengembangkan karakter religius siswa. Karena karakter religus sangat penting untuk dikembangkan pada siswa. Hal tersebut sesuai dengan Keputusan Menteri Pendidikan dan Kebudayaan RI Republik Indonesia Nomor 20 Tahun 2018 tentang Penguatan Karakter Pendidikan di satuan pendidikan formal bahwa sekokah perlu untuk memperkuat lima inti karakter bangsa dan salah satunya adalah nilai agama (Muhtar et al., 2019). Dengan adanya karakter religius pada siswa, akan menjadi benteng dari degradasi moral yang terjadi saat ini.

\section{Karakter Religius Siswa}

Dalam penelitian ini, peneliti fokus pada karakter religius, dikarenakan budaya sekolah yang mengutamakan nilai-nilai agama akan menghasilkan karakter religius pada siswa. Dimana karakter religius merupakan sikap dan perilaku yang patuh dalam melaksanakan ajaran agama yang dianut, toleran dalam pelaksanaan ibadah agama lain, dan hidup rukun dengan pemeluk agama lain.

Untuk menanamkan suatu karakter khususnya karakter religius diperlukan beberapa cara. Cara yang pertama yaitu dengan pembiasaan. Pembiasaanpembiasaan yang dilakukan di SD IT Noor Hidayah yaitu membiasakan dirinya untuk berwudhu sebelum mengerjakan sholat, melaksanakan sholat dhuha, sholat dzuhur, dan sholat ashar berjamaah. Pembiasaan tersebut sudah berjalan sangat lama. Akan tetapi berdasarkan hasil observasi yang dilakukan, belum semua siswa membiasakan dirinya untuk melaksanakan sholat berjaamah tepat waktu, melainkan ada saja siswa yang tidak melaksanakan sholat dan lebih memilih bermain dan pulang lebih awal sebelum sholat ashar.

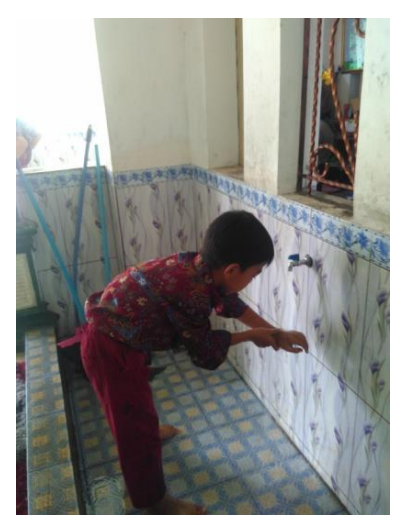

\section{Gambar 4. Pembiasaan Berwudhu Sebelum Sholat}

Cara yang kedua menurut (Ulwan, 2015) yaitu dengan memberikan keteladanan. Seorang guru menjadi teladan yang baik bagi siswanya, semua guru di SD IT Noor Hidayah sudah memberikan teladan yang baik bagi siswanya. Akan tetapi, belum semua siswa disana melaksanakan apa yang sudah dicontohkan gurunya. Ada siswa yang masih berkata kasar, bertengkar, dan tidak melaksanakan sholat. Hal itu terjadi karena faktor usia siswa yang masih kanak-kanak, sehingga masih belum bisa maksimal dalam menjalankan ajaran agama dengan baik, oleh karena itu guru harus bisa mengembangkan budaya sekolah terutama dalam bidang keagamaan yang dapat membentuk karakter religius. Sebab karakter religius saat ini sangat dibutuhkan oleh siswa untuk menghadapi perkembangan zaman. 


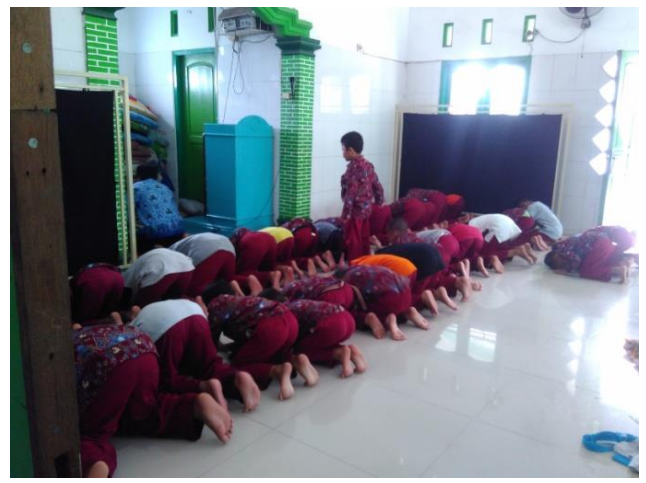

\section{Gambar 5. Contoh Keteladanan Guru (Menjadi Imam Saat Sholat Berjamaah)}

Adapun indikator dari karakter religius meliputi Mengucapkan salam; Berdo'a sebelum dan sesudah belajar; Melaksanakan ibadah keagamaan; dan Merayakan hari besar keagamaan (Labudasari \& Rochmah, 2018). Hal ini sejalan dengan pernyataan Kemendikbud dalam (Muhtar et al., 2019) bahwa religion is defined in the notion of character strengthening as an attitude that demonstrates faith in God Almighty, as demonstrated by having faith and pious behavior, cleanliness, tolerance, and love for the environment. Semua indikator yang telah disebutkan sudah terlaksana dan menjadi program sekolah di SD IT Noor Hidayah.

Untuk mengetahui karakter siswa di SD IT Noor Hidayah, peneliti memberikan angket pada responden (siswa) yang berisi 12 butir pernyataan pada masing-masing variabel. Angket dirancang sesuai dengan indikator karakter religius. Berdasarkan hasil angket didapatkan hasil bahwa pada kegiatan pembacaan doa memang sudah rutin dilaksanakan sebelum dan sesudah kegiatan pembelajaran. Hal tersebut sudah menjadi kewajiban. Sebanyak $41,2 \%$ responden yang menjawab selalu melakukan doa sebelum dan sesudah belajar dengan bersungguh-sungguh. Sisanya menjawab lupa dan tidak bersungguh-sungguh dalam berdoa. Jawaban serupa juga menjawab pertanyaan mengenai melaksanakan ibadah keagamaan. Sebagian besar menjawab melakukan ibadah bersama di sekolah namun permasalahannya pada saat waktu sholat tidak semua siswa laki-laki menuju ke musholah melainkan ada yang dikantin dan bermain air ketika wudhu, dan ada yang pulang sebelum sholat ashar. Oleh karena itu, budaya religius yang ada belum semuanya terlaksana. Hal ini dapat dibuktikan dengan melihat tabel distribusi frekuensi karakter siswa, dimana hanya $9.67 \%$ siswa yang memiliki karakter religius tinggi sehingga dapat disimpulkan jika karakter yang dimiliki siswa SD IT Noor Hidayah belum maksimal atau rendah.

Selama proses pengamatan di sekolah, didapatkan hasil bahwa proses pengembangan karaker religius dapat berjalan lancar dengan bantuan guru di dalamnya. Guru memiliki peran penting dalam kelancaran implementasi budaya sekolah keagamaan. Hal ini sejalan dengan pendapat (Agung Prihatmojo, 2020) bahwa pembentukan karakter di sekolah dibimbing oleh seluruh perangkat sekolah agar siswa mempunyai bekal moral. Pendapat yang sama dikemukakan oleh Saidek \& Islami dalam (Maharani et al., 2019) bahwa semua komponen sekolah harus terlibat dalam pendidikan karakter, meliputi masyarakat sekolah, kurikulum, pembelajaran, evaluasi dan aktivitas sekolah. Jadi, dalam hal ini seorang pendidik memiliki peran dalam mengkondisikan siswanya agar dapat menciptakan suasana budaya sekolah yang diharapkan dan dapat terlaksana dengan baik. 


\section{Pengaruh Budaya Sekolah terhadap Karakter Siswa}

Budaya sekolah memiliki peranan yang sangat penting dalam peningkatan karakter anak, dan dapat digunakan sebagai penentu dalam membedakan mutu antar sekolah. Budaya sekolah yang baik dapat dilihat dari hubungan antar warga sekolah, baik pada saat bekerja, kegiatan belajar-mengajar, maupun pada saat berkomunikasi satu sama lain. Budaya sekolah mencakup unsur artifak yakni berupa hal-hal yang dapat diamati secara langsung seperti tata ruang, kebiasan atau rutinitas, peraturanperaturan, simbol, logo, gambar-gambar, dan cara berpakaian warga sekolah (Suwandayani \& Isbadrianingtyas, 2017).

Sebuah sekolah harus mempunyai misi menciptakan budaya sekolah yang menyenangkan, cerdas, inovatif, religius, berakhlaq mulia, obyektif, dan normatif agar menghasilkan lulusan yang berkualitas tinggi dalam perkembangan intelektualnya dan memiliki karakter. Setiap sekolah harus dapat menciptakan budaya sekolahnya sendiri sebagai identitas dan memiliki rasa kebanggaan pada sekolahnya. Hal ini sudah diterapkan oleh SD IT Noor Hidayah, dimana sesuai dengan misi yang telah disebutkan, dan program-program sekolah yang dilakukan yaitu menjadikan program pendidikan islam sebagai program khusus, sehingga dapat berpengaruh pada perkembangan karakter religius siswa dan dapat mengembangkan budaya sekolah yang lebih baik. Budaya sekolah yang ada di SD IT Noor Hidayah yaitu 3S (Senyum, Sapa,Salam), sholat berjama'ah, mengaji, dll.

Faktor yang memberi pengaruh cukup besar terhadap pembentukan karakter adalah lingkungan dimana seseorang itu tumbuh dan dibesarkan di lingkungan keluarga, sekolah, dan sosial. Seorang anak memiliki waktu yang cukup banyak berada di lingkungan sekolah. Hal ini dirasakan oleh para siswa SD IT Noor Hidayah. Dimana sekolah tersebut merupakan sekolah yang memiliki program full day school dan memiliki budaya sekolah yang dapat mempengaruhi karakter religius siswa. Karakter religius merupakan sikap dan perilaku yang patuh dalam melaksanakan ajaran agama yang dianutnya, toleran terhadap agama lain, dan hidup rukun dengan pemeluk agama lain. Karakter religius sangatlah dibutuhkan oleh anak-anak agar mampu memiliki perilaku yang baik yang sesuai dengan ajaran agamanya, karena agama merupakan pedoman hidup bagi manusia.

Seberapa besar kontribusi budaya sekolah terhadap karakter siswa, terjawab melalui hasil pengujian validitas, realibilitas, normalitas, linearitas, korelasi, uji hipotesis, dan uji T. Data pada penelitian ini telah memenuhi syarat-syarat uji asumsi klasik yaitu kedua data variable $X$ dan $Y$ seluruhnya berdistribusi normal baik melalui hasil uji normal berdasarkan analisis grafik maupun analisis statistic. Nilai probabilitas data masing-masing variabel di peroleh angka berturut-turut sebesar 0,054 atau $05,4 \%$, dan 0,373 atau $37,3 \%$ yang seluruhnya lebih besar dari pada 0.05 atau $5 \%$. Selain data harus berdistribusi normal, kedua data juga harus memiliki hubungan yang linier. Baik linearitas data variabel $X$ terhadap variabel $Y$ maupun sebaliknya, linearitas data variabel $Y$ terhadap $X$. Dari tabel 4.5 hasil uji linearitas data variabel budaya sekolah terhadap variabel karakter siswa nilai $F$ hitung pada kolom $F$ baris deviation from linearity adalah 1,965 dan nilai $F$ tabel yang diperoleh dari table statistic dengan pembilang 12 dan penyebut 17 adalah 2,380 (tabel distribusi F) selanjutnya jika dibandingkan $F$ hitung terhadap $F$ table maka $F$ hitung $(1,965)<F$ table $(2,380)$ yang berarti kedua data adalah linear. Demikian juga pada nilai probabilitas atau nilai sig pada table diatas diperoleh sebesar 0,99 atau 9,9\% jika dibandingkan dengan signifikansi 0,05 atau 5\% maka 0,099 > 0,05 yang berarti kedua data adalah linear.

Selain itu, hasil uji dari tabel 4.6 nilai $F$ hitung pada kolom $F$ baris deviation from linearity adalah 0,629 dan nilai $F$ tabel yang diperoleh dari table statistic dengan pembilang 11 dan penyebut 18 adalah 2,370 (tabel distribusi $F$ ) selanjutnya jika dibandingkan $F$ hitung terhadap $F$ table maka $F$ hitung $(0,629)<F$ table $(2,370)$ yang berarti kedua data adalah linear. Begitu juga pada nilai probabilitas atau nilai sig pada 
table diatas diperoleh sebesar 0,782 atu 78,2 \% jika dibandingkan dengan signifikansi 0,05 atau $5 \%$ maka 0,782 >0,05 yang berarti kedua data adalah linear.

Jadi, kesimpulannya setelah dilakukan uji liniearitas data variabel $X$ terhadap data variabel $Y$ maupun sebaliknya linearitas data variabel $Y$ terhadap data variabel $X$ dengan ketentuan dan hasil uji sebagaimana yang telah disebutkan, maka dapat disimpulkan bahwa kedua data tersebut adalah linear dan kedua data tersebut telah memenuhi persyaratan analisis dan layak untuk dilanjutkan pada proses analisis selanjutnya.

Uji yang dilakukan selanjutnya yaitu uji korelasi, yang mana digunakan untuk membuktikan ada atau tidaknya pengaruh variabel $X$ terhadap Variabel $Y$ dan kedua variabel atau kedua data seharusnya memiliki hubungan atau korelasi baik korelasi positif maupun korelasi negative yang mengikat kedua data tersebut. Besarnya koefisien korelasi variabel budaya sekolah terhadap variabel karakter siswa diperoleh nilai koefisien (" $r$ ") korelasi sebesar 0,293. Nilai koefisien ("r") korelasi sebesar 0.293 menunjukkan bahwa adanya korelasi kedua variable pada katagori korelasi rendah. Sedangkan nilai Adjusted $R$ Square menunjukkan angka sebesar 0.054 atau 5,4\% yang berarti bahwa variable $Y$ dipengaruhi variable $X$ sebesar $54 \%$ sedangkan $46 \%$ di pengaruhi oleh faktor lain.

Dari hasil uji regresi menunjukkan bahwa kedua hipotesis yang diajukan dalam penelitian ini semuanya diterima yaitu ada pengaruh budaya sekolah terhadap karakter siswa di SD IT Noor Hidayah. Hasil analisis regresi terhadap kedua data penelitian dari perhitungan menghasilkan nilai konstanta variabel karakter siswa sebesar 40.040 dan koefisien regresi variabel budaya sekolah sebesar 0,292 bernilai positif yang berarti budaya sekolah berpengaruh positif terhadap karakter siswa. Pengaruh positif diartikan bahwa semakin baik warga sekolah dalam menerapkan budaya sekolah yang ada, maka akan semakin baik pula karakter warga sekolah termasuk siswanya. Dan nilai Sig. 0,01<0,05 berarti Ho ditolak.

Untuk mengetahui pengaruh variabel $x$ (budaya sekolah) terhadap variabel y (karakter siswa), dalam penelitian ini dilakukan uji T. Hasil uji T menunjukkan bahwa harga thitung variabel budaya sekolah terhadap karakter siswa sebesar 1.750 dengan tingkat signifikan sebesar Sig. 0.01 Adapun harga $t_{\text {tabel }}$ pada taraf signifikan $5 \%$ atau $\alpha=$ 0.05 dengan degree of freedom $(\mathrm{df})=\mathrm{N}-2$ dilihatpada table statistic diperoleh nilai $t_{\text {tabel }}$ sebesar 1,699.

Selanjutnya dengan mengikuti kaidah pengambilan keputusan pada uji t dapat dilihat bahwa $t_{\text {hitung }}=1.750$ lebih besar daripada $t_{\text {tabel }}=1,699$ maka Ha diterima dan Ho ditolak, yang berarti terdapat pengaruh signifikan variable budaya sekolah terhadap variable karakter siswa. Pengaruh tersebut sebesar 0,292 atau dengan kata lain 29,2 $\%$ variabel karakter siswa dipengaruhi oleh variabel budaya sekolah sedangkan sisanya dipengaruhi oleh faktor lain.

Hasil penelitian menunjukkan bahwa pengaruh budaya sekolah sebesar $29,2 \%$ terhadap karakter siswa. Hal itu sejalan dengan penanaman nilai-nilai karakter yang dapat dilihat saat proses kegiatan belajar mengajar, keteladanan, kegiatan rutin di sekolah serta pengembangan budaya sekolah yang ada. Berdasarkan hal tersebut maka ada pengaruh budaya sekolah terhadap karakter siswa di SD IT Noor Hidayah. Demikian juga dari analisis korelasi tampak adanya hubungan positif antara kedua variabel tersebut yang mengandung makna semakin baik budaya sekolah yang dirancang, maka semakin baik pula karakter warga sekolah terutama karakter siswanya. hal tersebut disebabkan karena budaya sekolah memberikan ruang pada siswa untuk melakukan pembiasaan yang positif dan berimbas pada penguatan karakter, seperti yang dijelaskan pada (Furkan, 2014) dan (Samong et al., 2016) bahwa budaya sekolah yang positif akan membantu kemajuan sekolah dan khususnya peningkatan mutu pendidikan karakter. 
Kesimpulannya adalah sekolah beserta kegiatan di dalamnya seperti budaya sekolah merupakan salah satu faktor yang dapat mempengaruhi karakter siswa. hal tersebut sejalan dengan Yusuf dalam (Tarmidzi \& Sugiarti, 2019) yang menjelaskan bahwa beberapa faktor yang dapat mempengaruhi perkembangan anak, diantaranya yaitu faktor keturunan (hereditas) dan lingkungan perkembangan. Lingkungan perkembangan siswa meliputi lingkungan keluarga, sekolah, teman sebaya, dan masyarakat. Sekolah memiliki peran sebagai pengganti lingkungan keluarga, sedangkan guru menjadi pengganti orang tua di lingkungan pendidikan yang formal, sehingga sekolah menjadi salah satu faktor penting penentu perkembangan pola pikir, sikap maupun perilaku anak. Dengan kata lain, sekolah bukan hanya menjadi tempat untuk memberikan ilmu tapi juga dapat mempengaruhi karakter siswa melalui kegiatan positif seperti budaya sekolah.

\section{SIMPULAN}

Berdasarkan hasil penelitian, dapat disimpulkan bahwa salah satu cara yang dilakukan oleh sekolah dalam rangka untuk meningkatkan karakter religius siswa adalah melalui budaya sekolah. Budaya sekolah yang diimplementasikan di SD IT Noor Hidayah yaitu budaya keagamaan. Budaya keagamaan yang sudah dilaksanakan di sekolah yaitu pembacaan do'a bersama di kelas; pembacaan surat-surat pendek AlQur'an, dan sholat dhuha dan sholat dzuhur berjamaah. Kegiatan tersebut sudah diterapkan dan sudah menjadi pembiasaan bagi warga sekolah khususnya siswa di SD IT Noor Hidayah dalam rangka untuk menumbuhkan karakter religius siswa. Siswa terbiasa untuk melaksanakan kegiatan ibadah seperti berdoa bersama ketika sebelum dan sesudah belajar, melakukan ibadah bersama di sekolah dan memperingati harihari besar keagaaman, meskipun belum maksimal. Hasil pengolahan data menunjukkan bahwa budaya sekolah berpengaruh sebesar $29,2 \%$ terhadap karakter siswa. Sisanya dipengaruhi oleh faktor lain. Tentunya karakter religius siswa dapat dipengaruhi secara positif oleh budaya sekolah karena pelaksanaannya dilakukan secara terus-menerus. Oleh sebab itu, perlu adanya dukungan dari masyarakat sekolah untuk bersama-sama memberikan komitmen dalam menanamkan nilai-nilai yang dapat diterapkan di lingkungan sekolah khususnya dalam bidang keagamaan.

\section{DAFTAR PUSTAKA}

Agung Prihatmojo, B. (2020). Pendidikan Karakter di Sekolah Dasar Mencegah Degradasi Moral di Era 4.0. DWIJA CENDEKIA, 4(1), 114-124.

Andari, L. (2013). Pengaruh Budaya Sekolah Terhadap Karakter Siswa. UIN Sunan Kali Jaga.

Anggraini, M. S. A., \& Zulfiati, H. M. (2017). IMPLEMENTASI PENDIDIKAN KARAKTER MELALUI BUDAYA SEKOLAH DI SD $N$ KOTAGEDE 3 YOGYAKARTA TAHUN AJARAN 2016/2017. Trihayu: Jurnal Pendidikan Ke-SDAn, 3(3), 151-158.

Arifa, F. C. (2017). Strategi Pembentukan Karakter Religius di SD Neegeri Wonokerto I Malang. Universitas Islam Negeri Maulana Malik Ibrahim Malang.

Arikunto, S. (2013). Prosedur Penelitian. Rineka Cipta.

Asmani, J. M. (2013). Buku Panduan Internalisasi Pendidikan Karakter di Sekolah. Diva Press.

Darmini, M. (2015). Pendidikan Karakter. UMC Press.

Daryanto \& Darmiatun, S. (2013). Implementasi Pendidikan Karakter Di Sekolah. Gava Media.

Fathurrohman, M. (2015). Budaya Religius Dalam Peningkatan Mutu Pendidikan. PT 
Refika Aditama.

Furkan, N. (2014). The Implentation of Character Education through the School Culture in Sma Negeri 1 Dompu and Sma Negeri Kilo Dompu Regency. Journal of Literature and Linguistics, 3(April 2009), 14-44.

Kurniawan, A. (2019). Analisis penanaman karakter religius siswa sekolah dasar kelas rendah di sekolah dasar berbasis islam di kota purwokerto.

Labudasari, E., \& Rochmah, E. (2018). Membangun karakter siswa sekolah dasar melalui gerakan literasi sekolah. Seminar Nasional Pendidikan Dasar, 25-32.

Maharani, S. D., MS, Z., \& Nadiroh, N. (2019). Transformation of The Value of Religious Characters in Civic Education Learning in Elementary Schools. International Journal of Multicultural and Multireligious Understanding, 6(2), 295. https://doi.org/10.18415/ijmmu.v6i2.683

Muhaimin. (2006). Nuansa Baru Pendidikan Islam Mengurai Benang Kusut Dunia Pendidikan. PT RajaGrafindo Persada.

Muhtar, T., Supriyadi, T., Lengkana, A. S., \& Hanifah, S. (2019). Religious charactersbased physical education learning in elementary school. International Journal of Learning, Teaching and Educational Research, 18(12), 211-239. https://doi.org/10.26803/ijlter.18.12.13

Nur, M. (2017). Kepemimpinan Kepala Sekolah dalam Mengmbangkan Budaya Agama di Sekolah. IAIN Antasari Banjarmasin.

Nurbaiti, R., Alwy, S., \& Taulabi, I. (2020). Pembentukan Karakter Religius Siswa Melalui Pembiasaan Aktivitas Keagamaan. EL Bidayah: Journal of Islamic Elementary Education, 2(1), 55-66. https://doi.org/10.33367/jiee.v2i1.995

Samong, F., Suryadi, A., \& Budimansyah, D. (2016). The Development of Character Education in Primary Schools through the Enhancement of School Culture. 77-79. https://doi.org/10.2991/icse-15.2016.17

Shoumi, N. B. (2017). PEMBENTUKAN KARAKTER RELIGIUS DAN DISIPLIN SISWA DI SD NEGERI 1 KOBER PURWOKERTO BARAT KABUPATEN BANYUMAS. INSTITUT AGAMA ISLAM NEGERI (IAIN) PURWOKERTO.

Silkyanti, F. (2019). Analisis Peran Budaya Sekolah yang Religius dalam Pembentukan Karakter Siswa. IVCEJ, 2(1), 36-42.

Supraptiningrum, \& Agustini. (2015). MEMBANGUN KARAKTER SISWA MELALUI BUDAYA SEKOLAH DI SEKOLAH DASAR. Jurnal Pendidikan Karakter, No. 2.

Suryana, E. dkk. (2013). Pembinaan Keberagamaan Siswa melalui Pengembangan Budaya Agama di SMA Negeri 16 Palembang. Ta'dib, Vol. XVIII(Vol. XVIII).

Suwandayani, B. I., \& Isbadrianingtyas, N. (2017). PERAN BUDAYA SEKOLAH DALAM PEMBENTUKAN KARAKTER ANAK SEKOLAH DASAR. Prosiding SENASGABUD, 34-41.

Suyadi. (2018). Strategi Pembelajaran Pendidikan Karakter. Remaja Rosdakarya.

Tarmidzi, T., \& Sugiarti, I. Y. (2019). Pengaruh Kultur Serta Kebiasaan dan Pembiasaan Positif di Sekolah Terhadap Karakter Religius dan Peduli Lingkungan Siswa SD di Kota Cirebon. DWIJA CENDEKIA: Jurnal Riset Pedagogik, 3(2), 248. https://doi.org/10.20961/jdc.v3i2.35192

Ulwan, A. N. (2015). Tarbiyatul Aulad Pendidikan Anak Dalam Islam. Insan Kamil.

Wahidin, K., et. al. (2010). Penelitian Pendidikan. UMC Press. 